\title{
A FAMILY OF IMPROVED ZVT PWM CONVERTERS USING AN AUXILIARY RESONANT SOURCE
}

\author{
M. L. Martins* \\ mariolsmeterra.com.br
}

\section{J. R. Pinheiro*}

\author{
H. Pinheiro*
}

H. A. Gründling*

\author{
H. L. Hey* \\ hey@ctlab.ufsm.br \\ *Power Electronics and Control Research Group - GEPOC, CT - Federal University of Santa Maria - UFSM \\ 97105-900 - Santa Maria - RS - Brazil
}

\begin{abstract}
This paper presents a novel family of Zero Voltage Transition (ZVT) DC-DC PWM Converters that uses a resonant circuit as auxiliary commutation source to control the current through the auxiliary switch without additional current stresses on main devices. The improved ZVT commutation cell enables the main switch to be turned on and off at Zero Voltage Switching (ZVS) and the auxiliary switch to be turned on and off at Zero Current Switching (ZCS) from zero to full-load.
\end{abstract}

KEYWORDS: DC-DC Converters, Zero-Voltage Transition, Auxiliary Resonant Source.

\section{RESUMO}

Este trabalho apresenta uma nova família de conversores CC-CC PWM ZVT os quais utilizam um circuito ressonante como fonte auxiliar para controlar a corrente através da chave auxiliar sem agregar esforços adicionais de corrente nos dispositivos principais. A célula de comutação aperfeiçoada possibilita a comutação da chave principal sob tensão nula e a comutação da chave

Artigo submetido em $23 / 5 / 2002$

1a. Revisão em $7 / 2 / 2003$

Aceito sob recomendação do Ed. Assoc. Prof. Antonio M. N. Lima auxiliar sob corrente nula desde carga nula até carga nominal.

PALAVRAS-CHAVE: Conversores CC-CC, Transição Sob Tensão Nula, Fonte Auxiliar Ressonante.

\section{INTRODUCTION}

Due to the current trend towards producing electronic equipments with higher efficiency, power density and EMI performance, the search for more efficient soft switching techniques becomes ever more intensive. Among these techniques, commutation at zero voltage termed Zero Voltage Transition: ZVT - has often been used in low and medium power applications. This is because of the low additional stresses added to the converter by the auxiliary commutation network located in parallel with the main power path, yielding low additional conduction losses when compared with other zero voltage switching techniques, Lee (1988) and Wang (1995).

Although ZVT is a well-accepted technique, several ZVT commutation cells proposed in the literature suffer drawbacks such as:

- turn-on capacitive losses at auxiliary switching, 
Hua (1992), Streit (1991);

- higher main switch current stresses, Yang (1993), Moschopoulos (1995) and (1996), Smith (1997) and Tseng (1998);

- higher auxiliary switch voltage stresses, Yang (1993) and Xu (2000);

- operation under limited voltage converter ratio, Filho (1994);

- additional components count, Menegáz (1999).

Among the ZVT commutation cell presented to date, the most attractive solution is presented by Martins (1993). However, it needs an autotransformer in the commutation cell to perform the auxiliary commutation source, which may increase the size and complexity of the converter. In addition, the auxiliary switch is turned off with the magnetizing current.

This paper proposes an improved ZVT commutation cell that uses a resonant tank as auxiliary commutation source, thereby eliminating some of the drawbacks mentioned above.

The paper is organized as follows: Section 2 introduces a family of Improved ZVT PWM DC-DC converters, and describes the operation principles of the improved ZVT boost converter. Section 3 sets out the soft commutation conditions. Section 4 gives a design guideline and presents an illustrative example. In Section 5 the feasibility of the proposed ZVT commutation cell is verified by means of experimental results obtained from a prototype rated at $1 \mathrm{~kW}$ operating at $100 \mathrm{kHz}$. Finally, Section 6 sets out conclusions from the analysis and the results drawn.

\section{PRINCIPLES OF OPERATION}

A new class of soft-switching converter was proposed by Hua (1992), namely ZVT PWM converters. These converters use a few additional elements placed in a parallel path with the main power circuit providing zero voltage commutation for the main switch without additional voltage and current stresses. Thus, this approach overcame the main drawbacks presented by ZVS-QRC converters, Lee (1988), and ZVS-PWM converters, Henze (1988). However, in Hua (1992) the auxiliary switch commutates with turn-on capacitive losses, reducing the overall efficiency gain and the EMI performance of these converters. To overcome these drawbacks this paper proposes an improved ZVT commutation cell shown in Fig. 1. It maintains the merits present in Hua (1992)

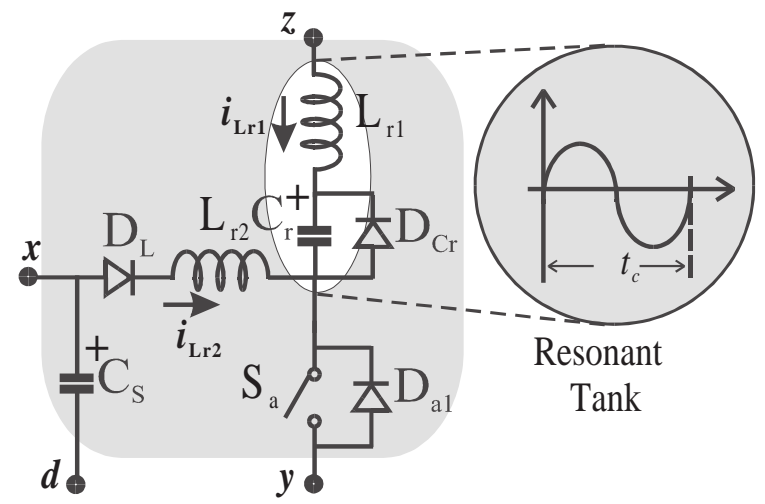

Figure 1: Improved ZVT Auxiliary Commutation Cell.

and furthermore, achieves soft switching at zero current (ZCS) for auxiliary switch. To obtain these characteristics a resonant tank, which plays the role of the auxiliary source, is used to control the current through the auxiliary switch. The resonant tank of Fig. 1 is represented by the inductor $\mathrm{L}_{r 1}$ and the capacitor $\mathrm{C}_{r}$.

Fig. 2 shows a family of improved ZVT PWM DCDC non-isolated converters obtained by incorporating the auxiliary resonant commutation cell to the common equivalent circuit of DC-DC converters presented by Irie (1990). It can be seen that the auxiliary commutation cell is placed in parallel with the main power path of each converter.

\subsection{Operation Principles of Improved ZVT Boost Converter.}

To analyze the operation of the proposed improved ZVT DC- DC PWM converters, the improved ZVT PWM boost converter was chosen. Fig. 3 shows the simplified diagram for this converter. It differs from the boost converter presented in Fig. 2(b) in terms of the following assumptions used in the analysis:

- the input inductor is large enough to be considered as a constant current source $I$ during one switching period;

- the output capacitor is large enough to be considered as a constant voltage source $V_{0}$;

- all the semiconductors are considered ideal.

In the steady state operation this converter assumes nine different circuit modes in one switching period. The description of each circuit mode is presented as follow. 

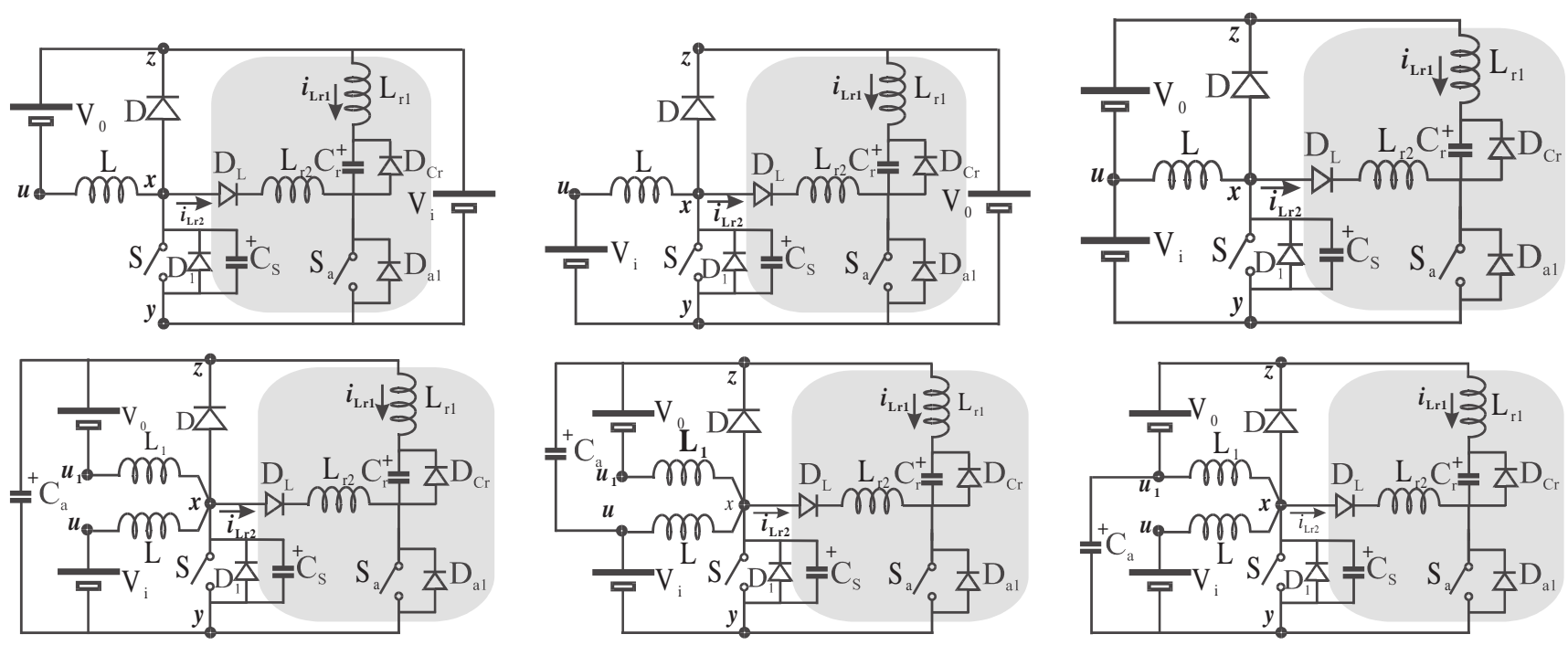

Figure 2: The Improved ZVT Family Converters.

Before the instant $t_{0}$ the diode $\mathrm{D}$ is conducting the input current $I$. The voltages across both switches are equal to the output converter voltage $V_{0}$ and voltage across auxiliary capacitor $\mathrm{C}_{r}$ is zero. The main theoretical waveforms during the main switch turn-on are presented in Fig. 4(a), whilst the turn-off and the PWM operation are presented in Fig. 4(b). The diagram of each circuit mode is presented in Fig. 5.

\subsubsection{Mode 1. $\left(t_{0}, t_{1}\right)$ :}

At $t_{0}$, the auxiliary switch $\mathrm{S}_{a}$ is turned on and starts a resonance process between $i_{L r 1}(t)$ and $v_{C r}(t)$. At the same time $i_{L r 2}(t)$ begins to increase linearly until it reaches the input current value. The voltage and current expressions to this mode are given by:

$$
\begin{gathered}
v_{C r}(t)=V_{0}-V_{0} \cos \left(\omega_{1} t\right), \\
i_{L r 1}(t)=\frac{V_{0}}{Z_{1}} \sin \left(\omega_{1} t\right) \\
v_{C s}(t)=V_{0} \\
i_{L r 2}(t)=\frac{V_{0}}{L_{r 2}} t
\end{gathered}
$$

The time interval of this mode is given by:

$$
\Delta t_{1}=t_{1}-t_{0}=\frac{I L_{r 2}}{V_{0}}
$$

Where the impedance $\mathrm{Z}_{1}$ is given by

$$
Z_{1}=\sqrt{\frac{L_{r 1}}{C_{r}}}
$$

and the resonant frequency $\omega_{1}$ by:

$$
\omega_{1}=\frac{1}{\sqrt{L_{r 1} C_{r}}}
$$

\subsubsection{Mode 2. $\left(\mathrm{t}_{1}, \mathrm{t}_{2}\right)$ :}

When the current through $\mathrm{L}_{r 2}$ is equal to $I$, boost diode $\mathrm{D}$ turns off and a resonant process begins between $i_{L r 2}(t)$ current and $v_{C s}(t)$ voltage. This process will completely discharge the energy stored into $\mathrm{C}_{s}$. This mode lasts until the current through the auxiliary switch reaches zero. The voltage and current behavior are given by the expressions:

$$
\begin{gathered}
v_{C r}(t)=V_{0}+\left(V_{C r}\left(t_{1}\right)-V_{0}\right) \cos \left(\omega_{1} t\right)+ \\
Z_{1} I_{L r 1}\left(t_{1}\right) \sin \left(\omega_{1} t\right) \\
i_{L r 1}(t)=\frac{\left(V_{0}-V_{C r}\left(t_{1}\right)\right)}{Z_{1}} \sin \left(\omega_{1} t\right)+I_{L r 1}\left(t_{1}\right) \cos \left(\omega_{1} t\right) \\
v_{C s}(t)=V_{0} \cos \left(\omega_{2} t\right) \\
i_{L r 2}(t)=I+\frac{V_{0}}{Z_{2}} \sin \left(\omega_{2} t\right)
\end{gathered}
$$

The time of this mode is given by:

$$
\Delta t_{2}=t_{2}-t_{1}=\frac{\pi+\sin ^{-1}\left(\frac{Z_{1}}{Z_{2}}\left(1+\frac{1}{k_{1}}\right)\right)}{\omega_{1}}-\frac{I Z_{2}}{V_{0} \omega_{2}}
$$




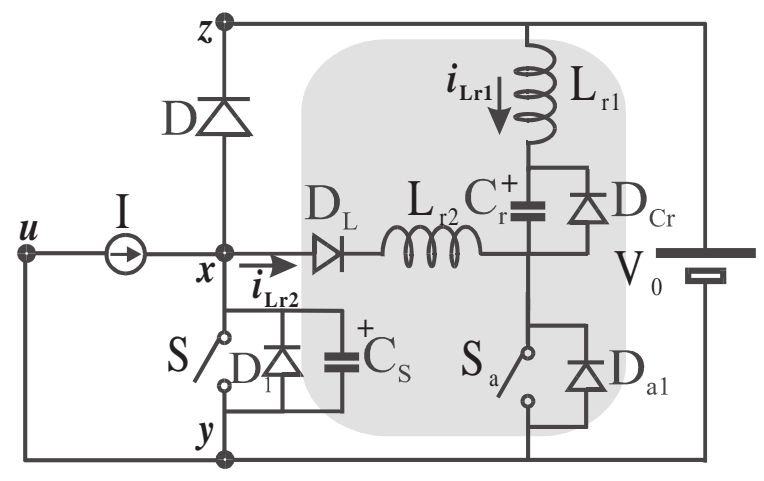

Figure 3: Improved ZVT Boost Converter.

where the impedance $Z_{2}$ is given by:

$$
Z_{2}=\sqrt{\frac{L_{r 2}}{C_{s}}}
$$

The resonant frequency is given by:

$$
\omega_{2}=\frac{1}{\sqrt{L_{r 2} C_{s}}}
$$

The factor $k_{1}$ defines the ratio between the overcurrent through inductor $\mathrm{L}_{r 2}$ defined as $\Delta I$ and the input current $I$ :

$$
k_{1}=\Delta I / I
$$

\subsubsection{Mode 3. $\left(\mathrm{t}_{2}, \mathrm{t}_{3}\right)$ :}

During this mode, the auxiliary switch body diode $\mathrm{D}_{a 1}$ turns on. This ensures the soft commutation conditions for the auxiliary switch turn-off. This circuit mode ends when the voltage $v_{C s}(t)$ reaches zero. The voltage and current expressions to this mode are given by:

$$
\begin{aligned}
& v_{C r}(t)=V_{0}+\left(V_{C r}\left(t_{2}\right)-V_{0}\right) \cos \left(\omega_{1} \cdot t\right)+ \\
& Z_{1} I_{L r 1}\left(t_{2}\right) \sin \left(\omega_{1} t\right) \\
& i_{L r 1}(t)=\frac{\left(V_{0}-V_{C r}\left(t_{2}\right)\right)}{Z_{1}} \sin \left(\omega_{1} t\right)+I_{L r 1}\left(t_{2}\right) \cos \left(\omega_{1} t\right) \\
& v_{C s}(t)=V_{0} \cos \left(\omega_{2} t\right)+Z_{2}\left(I-I_{L r 2}\left(t_{2}\right)\right) \sin \left(\omega_{2} t\right) \\
& i_{L r 2}(t)=I+\frac{V_{0}}{Z_{2}} \sin \left(\omega_{2} t\right)+\left(I_{L r 2}\left(t_{2}\right)-I\right) \cos \left(\omega_{2} t\right)
\end{aligned}
$$

The time of this mode is given by:

$$
\Delta t_{3}=t_{3}-t_{2}=\frac{\pi-2 \sin ^{-1}\left(\frac{Z_{1}}{Z_{2}}\left(1+\frac{1}{k_{1}}\right)\right)}{\omega_{1}}
$$

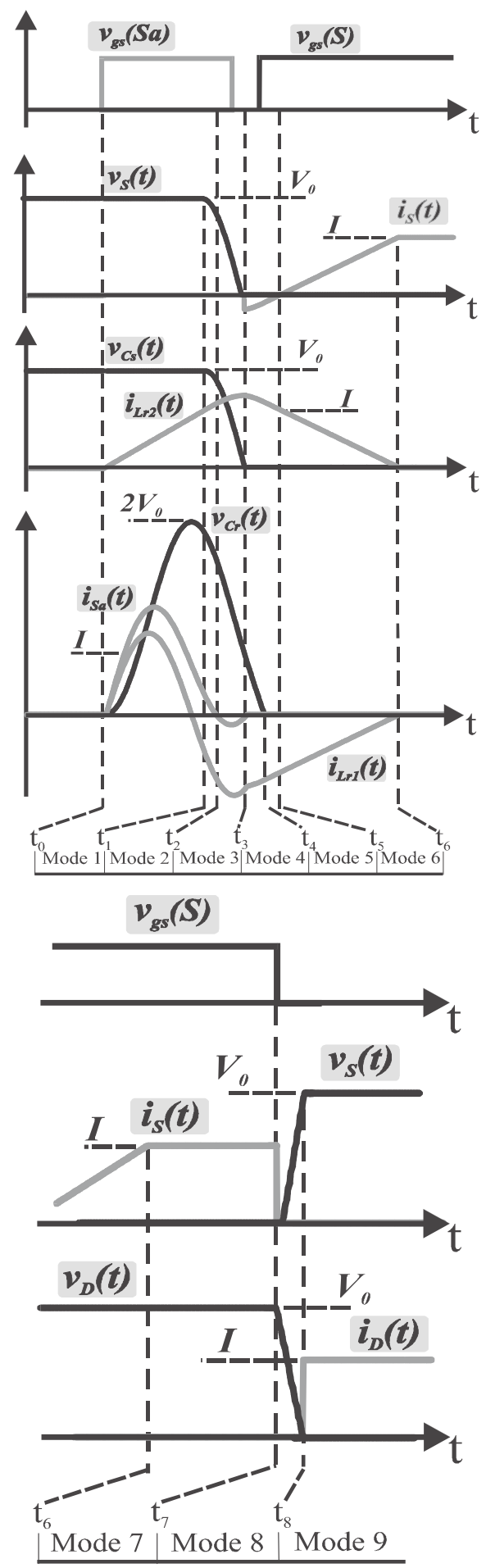

Figure 4: Main theoretical waveforms: (a) Turn-on modes; (b) PWM and turn-off modes.

\subsubsection{Mode 4. $\left(\mathrm{t}_{3}, \mathrm{t}_{4}\right)$ :}

At $\mathrm{t}_{3}$, voltage $v_{C s}(t)$ reaches zero and the main switch body diode $\mathrm{D}_{1}$ turns on, ensuring the soft commutation 
conditions for its turn-on with ZVS. At the same instant $\mathrm{D}_{a 1}$ turns off and the current $i_{L r 2}(t)$ decreases in a resonant fashion through $\mathrm{L}_{r 1}, \mathrm{~L}_{r 2}$ and $\mathrm{C}_{r}$. This mode ends when $v_{C r}(t)$ reaches zero and the voltage boosting diode $\mathrm{D}_{C r}$ turns on. The voltage and current expressions to this mode are given by:

$$
\begin{gathered}
v_{C r}(t)=V_{0}+\left(V_{C r}\left(t_{3}\right)-V_{0}\right) \cos \left(\omega_{3} t\right)+ \\
I_{L r 1}\left(t_{3}\right) \sin \left(\omega_{3} t\right) \\
i_{L r 1}(t)=\frac{\left(V_{C r}\left(t_{3}\right)-V_{0}\right)}{Z_{3}} \sin \left(\omega_{3} t\right)+I_{L r 1}\left(t_{3}\right) \cos \left(\omega_{3} t\right) \\
v_{C s}(t)=0 \\
i_{L r 2}(t)=-i_{L r 1}(t)
\end{gathered}
$$

The time of this mode is given by:

$$
\begin{aligned}
\Delta t_{4} & =t_{4}-t_{3} \\
& =\frac{\sin ^{-1}\left(\frac{Z_{1}}{Z_{2}}\left(1+\frac{1}{k_{1}}\right)\right)-\tan ^{-1}\left(\frac{Z_{1} I_{L r 1}\left(t_{4}\right)}{V_{0}}\right)+\alpha}{\omega_{3}}
\end{aligned}
$$

where the angle $\alpha$ is given in the Appendix. The impedance $Z_{3}$ is given by:

$$
Z_{3}=\sqrt{\frac{L_{r 1}+L_{r 2}}{C_{r}}}
$$

and the resonant frequency $\omega_{3}$ by:

$$
\omega_{3}=\frac{1}{\sqrt{\left(L_{r 1}+L_{r 2}\right) C_{r}}}
$$

\subsubsection{Mode 5. $\left(t_{4}, t_{5}\right)$ :}

At $\mathrm{t}_{4}$, the currents through $i_{L r 2}(t)$ and $i_{L r 1}(t)$ decrease linearly until it reaches $I$, when $\mathrm{D}_{1}$ is turned off. The voltage and current expressions to this mode are given by:

$$
\begin{gathered}
v_{C r}(t)=0 \\
i_{L r 1}(t)=\frac{V_{0}}{L_{r 1}+L_{r 2}} t+I_{L r 1}\left(t_{4}\right) \\
v_{C s}(t)=0 \\
i_{L r 2}(t)=-i_{L r 1}(t)
\end{gathered}
$$

The time of this mode is given by:

$$
\Delta t_{5}=t_{5}-t_{4}=\frac{\left(I-I_{L r 1}\left(t_{4}\right)\right)\left(L_{r 1}+L_{r 2}\right)}{V_{0}}
$$
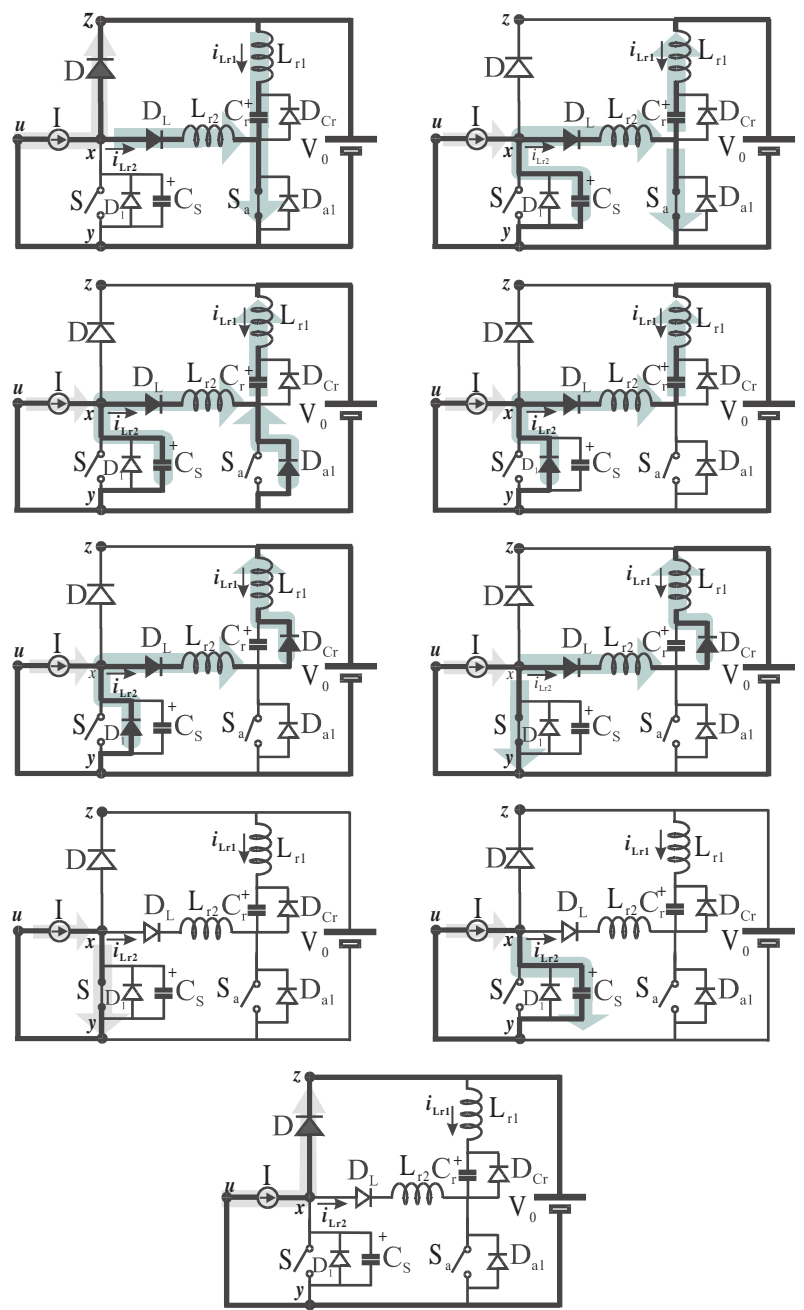

Figure 5: The Improved ZVT Family Converters.

\subsubsection{Mode 6. $\left(\mathrm{t}_{5}, \mathrm{t}_{6}\right)$ :}

The current $i_{L r 2}(t)$ continues to ramp down until it reaches zero and the current through main switch $\mathrm{S}$ reaches $I$. In this mode, the expressions to the voltages and currents are the same as in Mode 5. The time of this mode is given by:

$$
\Delta t_{6}=t_{6}-t_{5}=\frac{I_{L r 1}\left(t_{5}\right)\left(L_{r 1}+L_{r 2}\right)}{V_{0}}
$$

\subsubsection{Mode 7. $\left(\mathbf{t}_{6}, \mathbf{t}_{7}\right)$ :}

The operation of the circuit at this mode is similar to its hard-switching counterpart. The input current flows through the main switch $\mathrm{S}$. The time of this mode is given by the duty-cycle of the PWM modulation. 


\subsubsection{Mode 8. $\left(\mathrm{t}_{7}, \mathrm{t}_{8}\right)$ :}

At $t_{7}$, the main switch $\mathrm{S}$ is turned off and the current $I$ is diverted to the snubber capacitor $\mathrm{C}_{s}$ and its voltage is linearly charged up to output converter voltage $V_{0}$. The voltage and current expressions to this mode are given by:

$$
\begin{gathered}
v_{C r}(t)=0 \\
i_{L r 1}(t)=0 \\
v_{C s}(t)=\frac{I}{C_{s}} t \\
i_{L r 2}(t)=0
\end{gathered}
$$

The time of this mode is given by:

$$
\Delta t_{8}=t_{8}-t_{7}=\frac{C_{s} V_{0}}{I}
$$

\subsubsection{Mode 9. $\left(t_{8}, t_{9}\right)$ :}

When $v_{C s}(t)$ voltage reaches $V_{0}$, the boost diode $\mathrm{D}$ turns on, and another switching cycle begins.

\section{SOFT COMMUTATION CONDITIONS}

\subsection{Main switch turn-off (ZVS)}

As described in Mode 8 of Section 2, after main switch S is turned off, the input current is diverted from switch to a snubber capacitor $\mathrm{C}_{s}$. As a result, voltage across the main switch increases with controlled $d v / d t$ achieving zero voltage turn-off. The capacitance value is given by expression (39) as follows:

$$
C_{s}=\frac{I t_{f}}{2 k_{s} V_{0}}
$$

where $t_{f}$ is the fall time of the semiconductor device used and factor $k_{s}$ is chosen to reduce the commutation energy dissipated by the semiconductor. The range of $k_{s}$ is defined below:

$$
0<k_{s}<1
$$

\subsection{Main switch turn-on (ZVS/ZCS)}

To achieve main switch turn-on without losses, it is initially necessary to divert the input current from boost diode $\mathrm{D}$ to inductance $\mathrm{L}_{r 2}$ and after, to discharge completely the snubber capacitor $\mathrm{C}_{s}$. This way the resonant process between $i_{L r 2}(t)$ and $v_{C s}(t)$ must lasts until
$v_{C s}(t)$ achieves zero. This condition is assured by the following expression:

$$
\omega_{1}=\frac{2 k_{1} \omega_{2}\left(2 \pi-\sin ^{-1}\left(\frac{Z_{1}}{Z_{2}}\left(1+\frac{1}{k_{1}}\right)\right)\right)}{\left(2+k_{1} \pi\right)}
$$

\subsection{Auxiliary switch turn-on (ZCS)}

As described in Modes 1 and 2 of Section II, by the presence of inductors $\mathrm{L}_{r 1}$ and $\mathrm{L}_{r 2}$ current through auxiliary switch $\mathrm{S}_{a}$ increases with controlled $d i / d t$ achieving zero current turn-on. Furthermore, by an appropriate choice of $\mathrm{L}_{r 2}$, the reverse-recovery losses of boost diode $\mathrm{D}$ can be minimized. The expression (42) can be used to choose the inductance $L_{r 2}$ :

$$
L_{r 2}>\frac{V_{0}}{\left(\frac{d}{d t} i_{D}\right)}
$$

where $\frac{d}{d t} i_{D}$ is the turn-off di/dt rate of the boost diode.

\subsection{Auxiliary switch turn-off (ZCS/ZVS)}

To assure the conduction of diode $\mathrm{D}_{a 1}$, ensuring the auxiliary switch turn-off without losses, the following relation between the characteristics impedances must be satisfied:

$$
\frac{Z_{1}}{Z_{2}}=\frac{k_{1}}{k_{2}\left(1+k_{1}\right)}
$$

where the constant $k_{2}$ must be greater than one and is defined as the ratio between the maximum values of current through each one of the resonant inductors $\mathrm{L}_{r 1}$ and $\mathrm{L}_{r 2}$ as shown below:

$$
k_{2}=\frac{I_{L r 1(\max )}}{I_{L r 2(\max )}}>1
$$

\section{DESIGN GUIDELINES}

This section describes a design procedure and gives an example of how to determine the component values of the proposed improved ZVT PWM boost converter.

The input data are defined as follows:

- Output Power: $P_{0}=1000 \mathrm{~W}$

- Output Voltage: $V_{0}=400 \mathrm{~V}$

- Input Voltage: $V_{i}=150 \mathrm{~V}( \pm 10 \%)$ 
- Operation Frequency: $f_{s}=100 \mathrm{kHz}$

- Minimum estimate efficiency: $\eta \geq 95 \%$

The design guidelines consist of the following eleven steps:

1. The value of the capacitance $\mathrm{C}_{s}$ can be determined by a turn-off capacitive snubber procedure as presented by Mohan (1995). However, to minimize the number of auxiliary components, in this example, $\mathrm{C}_{s}$ is adopted as the intrinsic output capacitance of the semiconductor device (MOSFET - IRP450). Thus, $\mathrm{C}_{s}$ is defined as: $C_{s}=C_{o s s}=0.4 n F$

2. From the output power and the minimum estimate efficiency, the input power is defined: $P_{i}=\frac{P_{0}}{\eta}=$ $1050 \mathrm{~W}$

3. From the input power and the input voltage, the input current is defined by: $I=\frac{P_{i}}{V_{i}}=7.0 \mathrm{~A}$

4. The inductance $\mathrm{L}_{r 2}$ is obtained from the expression (48) where the factor $k_{1}$ is chosen as equal to $k_{1}$ $=0.25 . L_{r 2}=\frac{C_{s}}{k_{1}^{2}}\left(\frac{V_{0}}{I}\right)^{2}=22.15 \mu H$

5. The impedance $Z_{2}$ is calculated by: $Z_{2}=\sqrt{\frac{L_{r 2}}{C_{s}}}=$ $235.3 \Omega$

6. The resonant frequency $\omega_{2}$ is calculated by: $\omega_{2}=$ $\frac{1}{\sqrt{L_{r 2} C_{s}}}=10.62 \mathrm{Mrad} / \mathrm{s}$

7. To ensure ZCS commutation to switch $\mathrm{S}_{a}, k_{2}$ is defined by (44) and was chosen equal to $k_{2}=1.1$ :

8. Substituting $k_{2}$ and $k_{1}$ values in expression (43), the impedance $Z_{1}$ is given by: $Z_{1}=42.79 \Omega$

9. From the expression (41), $\omega_{1}$ is: $\omega_{1}=9.8 \mathrm{Mrad} / \mathrm{s}$

10. The inductance of the resonant tank is given by: $L_{r 1}=\frac{Z_{1}}{\omega_{1}}=4.36 \mu \mathrm{H}$

11. The capacitance of the resonant tank is given by: $C_{r}=\frac{1}{Z_{1} \omega_{1}}=2.38 n F$

\section{EXPERIMENTAL RESULTS}

Following the design example shown in Section 4, a 100 $\mathrm{kHz}, 1 \mathrm{~kW}$ improved ZVT PWM boost converter prototype has been implemented to verify the operation and the performance of the proposed improved ZVT commutation cell. The power circuit operates from a $150 \mathrm{~V}$ DC voltage source and supplies a $400 \mathrm{~V}$ resistive load as shown in Fig. 6. Its main parameters are summarized in



Figure 6: Improved ZVT Auxiliary Commutation Cell.

Table 1: Experimental Parameters

\begin{tabular}{|c|c|}
\hline Component & Parameter \\
\hline$V_{i}$ (input voltage) & $150 \mathrm{~V}$ \\
\hline$V_{0}$ (output voltage) & $400 \mathrm{~V}$ \\
\hline$P_{0}$ (output power) & $1.0 \mathrm{~kW}$ \\
\hline$f_{s}$ (switching frequency) & $100 \mathrm{kHz}$ \\
\hline$L$ (input filter) & $0.91 \mathrm{mH}$ \\
\hline$C$ (output filter) & $150 \mathrm{uF}$ \\
\hline$S$ (main switch) & IRFP 450 \\
\hline$S_{a}$ (auxiliary switch) & HGTP7N60C3D \\
\hline$D$ (boost diode) & MUR 1560 \\
\hline$D_{L}$ (blocking diode) & MUR 1560 \\
\hline$D_{b}$ (auxiliary diode) & RHRP 8120 \\
\hline$L_{r 1}$ (resonant inductor) & $3.5 \mu \mathrm{H}$ \\
\hline$L_{r 2}$ (resonant inductor) & $21.7 \mu \mathrm{H}$ \\
\hline$C_{s}$ (resonant capacitor) & $400 \mathrm{pF}\left(\mathrm{C}_{s}=\mathrm{C}_{\text {oss }}\right)$ \\
\hline$C_{r}$ (resonant capacitor) & $3.0 \mathrm{nF}(=2 \times 1.5 \mathrm{nF})$ \\
\hline
\end{tabular}

Table I. The main switch used was IRFP450 (MOSFET) and the auxiliary switch used was HGTP7N60C3D (600 V, 7 A) UFS (Ultra Fast Switches) series IGBT from Intersil Semiconductors, which present a built-in, antiparallel hyperfast diode. To reduce the auxiliary semiconductors parasitic capacitance effects in the auxiliary circuit, a saturable reactor implemented with 8 turns on a Toshiba "spike killer" core (SA14x8x4.5) was used, as well as a clamped circuit represented by the dashed lines in the power stage circuit diagram, Fig. 6.

As can be seen in Fig. 7(a), the gate-source signal of switch $\mathrm{S}$, is applied only after the voltage $v_{D S}$ reaches zero, characterizing the zero voltage turn-on.

To assure ZCS turn-off at auxiliary switch, its gatesource signal is removed after the current through it reaches zero, as shown in Fig. 10(b). The ZCS con- 
ditions achieved to auxiliary switch permit the use of minority carrier devices which are more appropriate for these conditions. As a result, the turn-on capacitive losses presented by the ZVT converters proposed in Hua (1992), Streit (1991) and Menegáz (1999) are considerably reduced.

Fig. 7(c) shows the voltage across the resonant capacitor $\mathrm{C}_{r}$ and the current through resonant inductors $\mathrm{L}_{r 1}$ and $\mathrm{L}_{r 2}$.

Figure 8 shows the measured efficiency of the boost converter with the improved ZVT commutation cell as function of the output power, whose value was approximately equal to $96.5 \%$ at full load $(1 \mathrm{~kW})$. For comparison purposes, Fig. 11 also includes the efficiency curves of the conventional ZVT boost converter, Hua (1992), and its hard-switching counterpart. The measured efficiencies at full load were, respectively, 96.1\% and $94.3 \%$. Using the resonant tank, the ZCS conditions are achieved to the auxiliary switch, so that the turn-on capacitive losses presented in Hua (1992) are avoided, ensuring an efficiency gain by the proposed converter for high load conditions. As the tank energy is proportional to the converter voltage output $\mathrm{V}_{0}$, the circulating reactive energy is maintained almost constant for whole load range, which mitigates the efficiency gain obtained with the auxiliary switch ZCS operation at low load conditions.

\section{CONCLUSIONS}

A family of Improved ZVT PWM converters is presented. These converters retain the merits of ZVT proposed by Hua (1992): namely, neither voltage nor current stress on main devices, and low additional conduction losses when compared to its PWM counterpart. Furthermore, soft switching at zero current (ZCS) for the auxiliary switch is achieved, which is more suitable for minority carrier devices, allowing the reduction of converter switching losses.

To obtain these characteristics without the presence of a DC voltage source in the auxiliary circuit, a resonant tank is used as auxiliary commutation source. It controls the current flux between main power and auxiliar circuits. In addition, it also controls the current through the auxiliary switch without additional current stresses on main switch as presented in Yang (1993), Moschopoulos (1995, 1996), Smith (1997) and Tseng (1998).

Operating principles and commutation process are described and verified by experimental results, which were obtained from a prototype of $1 \mathrm{~kW}$ operating at $100 \mathrm{kHz}$,

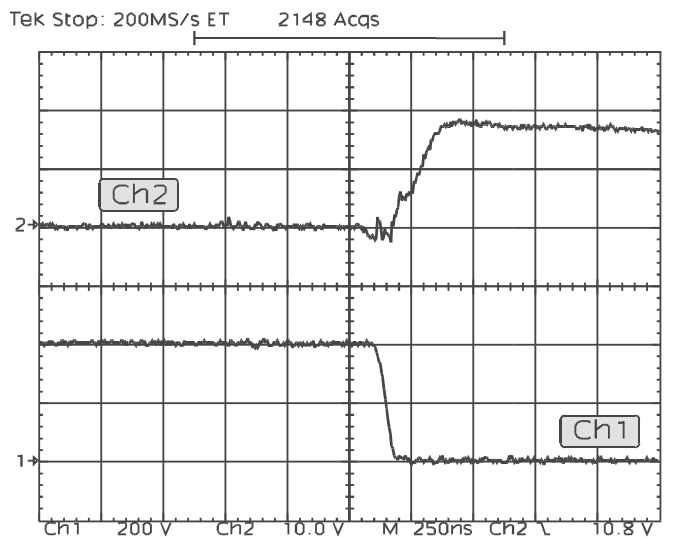

(a) Main Switch: Ch1 - vDS(t), Ch2 -vGS(t).

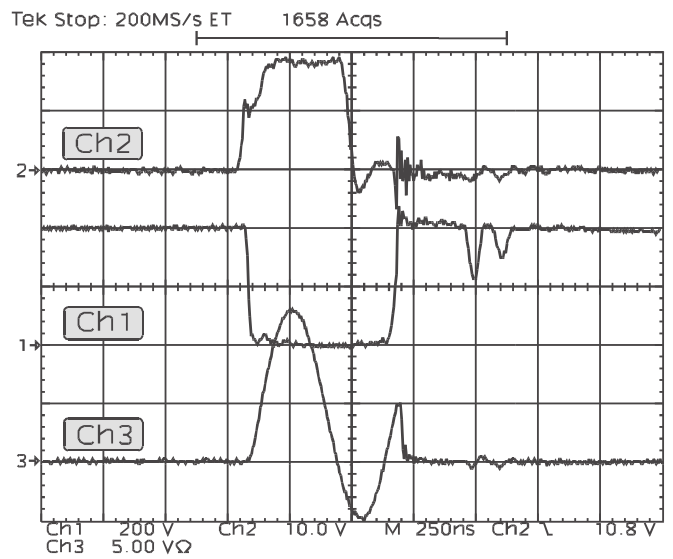

(b) Auxiliary Switch: Ch1 - vCE(t), $\mathrm{Ch} 2-\mathrm{vGE}(\mathrm{t}), \mathrm{Ch} 3-\mathrm{iC}(\mathrm{t})$.

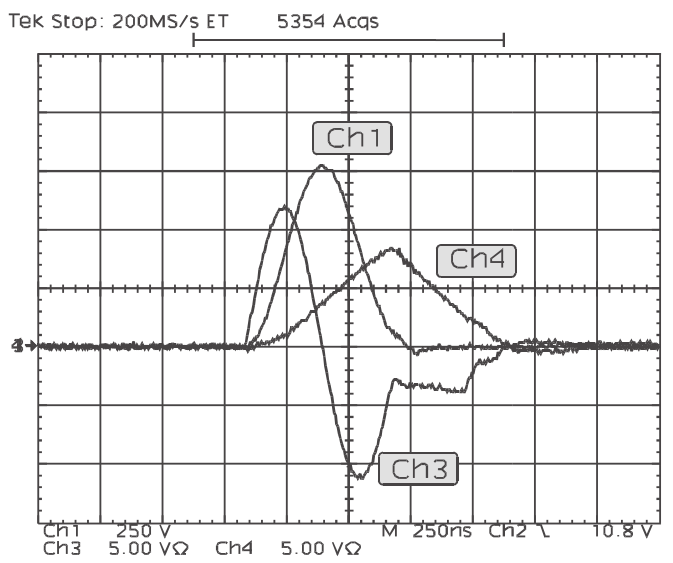

(c) Resonant Elements: $\mathrm{Ch} 1 \mathrm{vCr}(\mathrm{t}), \mathrm{Ch} 3-\mathrm{iLr} 1(\mathrm{t})$, Ch4 - iLr2(t), Time $=250 \mathrm{~ns} /$ div.

Figure 7: Experimental results.

giving an efficiency gain when compared to the conventional ZVT and to its PWM hard-switch counterpart at full load. 




Figure 8: Converters efficiencies.

\section{ACKNOWLEDGMENT}

The authors would like to express their special thanks to Thornton Inpec Eletrônica Ltda and Icotron - an EPCOS Company and Toshiba do Brasil S.A. for material support.

\section{A APPENDIX}

The angle $\alpha$ is defined by the expression below:

$$
\alpha=\alpha_{1}-\alpha_{2}+\alpha_{3}
$$

where:

$$
\begin{gathered}
\alpha_{1}=\sin ^{-1}\left(\frac{Z_{1}}{Z_{2}}\left(1+\frac{1}{k_{1}}\right)\right) \\
\alpha_{2}=t g^{-1}\left(\frac{Z_{1} I_{L r 1}\left(t_{4}\right)}{V_{0}}\right) \\
\alpha_{3}=\sin ^{-1}\left(\left(Z_{3}-Z_{1}\right)\left(1+k_{1}\right) I \cos \left(\frac{\pi}{2}-\alpha_{1}\right)\right. \\
\left.\cos \left(\alpha_{2}\right) \tan \left(\frac{\pi}{2}-\alpha_{1}\right)\right)
\end{gathered}
$$

\section{REFERENCES}

Filho, N. P., Farias, V. J. and Freitas, L. C. (1994). A Novel Family of DC-DC PWM Converters Using the Self-resonant Principle. Proc. of the 25th Power Electronics Specialists Conference PESC'94, pp. 1385-1391.

Henze, C. P., Martin H. C. and Parsley, D. W. (1988). Zero-Voltage-switching in High Frequency Power Converters Using Pulse Width Modulation. Proc. of the 3rd Conference on Applied Power Electronics and Exposition APEC'88, pp. 33-44.
Hua, G.; Leu, C. and Lee, F. C (1992). Novel ZeroVoltage Transition PWM Converters. Proc. of the 23th Power Electronics Specialists Conference PESC'92, pp. 55-60.

Irie, H. (1990) Resonant Switches in Common Equivalent Circuit of DC/DC Converters. Proc. of the 2nd International Power Electronics Conference IPEC'90, pp. 362-368.

Lee, F. C. (1988). High-frequency Quasi-resonant Converter Topologies. Proc. of the IEEE, Vol.76, No. 4, pp. 377-390.

Martins, D. C.; Seixas, F. J.; Barbi, I. and Brilhante, J. A. (1993). A Family of DC-to-DC PWM Converters Using a New ZVS Commutation Cell. Proc. of the 24th Power Electronics Specialists Conference PESC'93, pp. 524-530.

Menegáz, P. J. M.; Có, M. A.; Simonetti, F. C and Vieira, J. L. F. (1999). Improving the Operation of ZVT DC-DC Converters. Proc. of the 30th Power Electronics Specialists Conference PESC'99, pp. 293-297.

Mohan, N.; Undeland, T. M. and Robbins, W. P. (1995). Power Electronics - Converters, Applications and Design. 2 Ed., John Wiley \& Sons, NY.

Moschopoulos, G.; Jain, P. and Joos, G. (1995). A Novel Zero-Voltage Switched PWM Boost Converter. Proc. of the 26th Power Electronics Specialists Conference PESC'95, pp. 694-700.

Moschopoulos, G.; Jain, P.; Joos, G. and Liu, Y. (1996). A Zero-Voltage Switched PWM Boost Converter With na Energy Feedforward Auxiliary Circuit. Proc. of the 27th Power Electronics Specialists Conference PESC'96, pp. 76-82.

Streit, R. and Tollik, (1991), A High Efficiency Telecom Rectifier Using A Novel Soft-switched Boost-based Input Current Shaper. Proc. of the 13th Telecommunication Energy Conference INTELEC'91, pp. 720-726.

Smith, K. M. and Smedley, K. M. (1997). A Comparison of Voltage-Mode Soft-switching Methods for PWM Converters. Trans. on Power Electronics, Vol. 12, $\mathrm{n}^{\circ} .2$, pp. $376-386$.

Tseng, C. and Chen, C. (1998). Novel ZVT-PWM Converters With Active Snubbers. Trans. on Power Electronics, Vol. 13, $\mathrm{n}^{o} .5$, pp. 861-869. 
Wang, K., Hua, G. and Chen, C. (1995). Analysis, Design and Experimental Results of ZCS-PWM Boost Converters. Proc. of the 3rd International Power Electronics Conference IPEC'95, pp. 1197-1202.

Xu, D. M.; Zhang, J. M.; Ren, Y. C. and Qian, Z. (2000). A Novel Single-phase Active-clamped ZVT-PWM Converter. Proc. of the 15th Conference on Applied Power Electronics and Exposition APEC'00, pp. 456-459.

Yang, L. and Lee, C. Q. (1993). Analysis and Design of Zero-Voltage Transition PWM Converter. Proc. of the 8th Conference on Applied Power Electronics and Exposition APEC'93, pp. 707-713. 